\title{
5 \\ The New Framework for Pacific Regionalism: Old kava in a new tanoa?
}

\section{Claire Slatter}

In October 2005, in Port Moresby, Pacific Island leaders adopted the Pacific Plan. Described as 'the master strategy for strengthening regional cooperation and integration in the Pacific', it was greeted with much criticism from academics, non-government organisations (NGOs) and citizens' groups in the region. ${ }^{1}$ The outcome of an Eminent Persons Group (EPG) set up by the Pacific Islands Forum in 2003, the Pacific Plan was first of all seen as the brainchild of New Zealand, particularly several senior civil servants from New Zealand including Department of Foreign Affairs and Trade personnel, who were part of the team supporting the EPG, were believed to have largely authored it. The plan was criticised for paying lip service to Pacific values and cultures, while primarily endorsing a neoliberal economic agenda that ran counter to Pacific peoples' interests. Critics argued that it failed to address the needs of Pacific people, particularly the poor and marginalised, and was out of touch with the lived realities of Pacific Islanders (Coates 2006, p. 3).

\footnotetext{
1 Oxfam New Zealand's Executive Director at the time, Barry Coates, cited the following criticisms of the Pacific Plan by civil society organisations, academics and community representatives: 'a lack of genuine consultation, the lack of focus on the needs of those who suffer hardship and injustice, and insufficient connection to the reality of people's lives' (Coates 2006).
} 
The 2013 review of the Pacific Plan offered an opportunity to imagine a future desired by Pacific Island people, and to create an authentically Islander-centred development framework. Public submissions received by the review team, headed by former Papua New Guinea Prime Minister Sir Mekere Morauta, reportedly included 37 submissions from civil society organisations (CSOs) and/or leaders, out of a total of 65 submissions. Delivering the final report to Pacific leaders on 31 October 2013, Sir Mekere Morauta called for 'a new level and quality of political debate, policy and cooperation at the regional level'. The report contained 36 recommendations to Pacific leaders, and a draft New Framework for Pacific Regionalism. The draft framework was widely circulated for feedback before a finalised version was adopted by Pacific leaders in Palau in July 2014.

How new is the New Framework for Pacific Regionalism? How different is it from its earlier iteration? Does it reflect any of the concerns and ideas expressed in civil society submissions to the review team? Does the New Framework for Pacific Regionalism inspire confidence in Pacific leadership and ownership of our leaders' vision? Or does it sorely disappoint by offering Pacific Island people more of the same?

This chapter examines the New Framework for Pacific Regionalism and assesses the extent to which it reflects alternative views and visions of a Pacific future that have been gaining currency over the last two decades. The chapter begins by revisiting the strong criticism that emerged within the region almost ten years ago in response to the Pacific Plan, and situating the Pacific Plan within the broader programme of economic restructuring and trade liberalisation in the region of which it is an integral part. It then examines the extent to which the new Pacific framework responds to these criticisms.

\section{Revisiting Criticisms of the Pacific Plan}

In her trenchant critique of the Pacific Plan, Elise Huffer (2006a) began by tracing its origin to the 2003 proposal by the then New Zealand Prime Minister Helen Clark, as Chair of the Pacific Islands Forum, for a review of 'the role, functions and Secretariat' of the Pacific Islands Forum. As such, in Huffer's view, the Pacific Plan was 'intimately tied to the redefining of the Pacific Islands Forum', a body which she criticised as representing 'only heads of governments and states', which did not 'create space for wider discussion of important regional matters by citizens of Forum Islands Countries', and whose secretariat was 'distant from the peoples of the region, as well as hierarchical and technocratic' (Huffer 2006a, p. 159). 
An EPG, led by Sir Julius Chan, former prime minister of Papua New Guinea, had been tasked with the job of reviewing the Pacific Islands Forum (PIF) and had produced a report titled 'Pacific Cooperation: Views of the region' (EPG 2004). The report alludes to modernisation and globalisation as if they were autonomous forces that, despite 'bringing wonders to our shores', had 'exposed the vulnerability of our small island states ... threatened our family and community bonds and values, weakened our ability to live off the land and sea, and upset our harmony with the natural environment'. Apparently denying any agency on the part of states and governments in exposing island states to these threats, the report asserted a will to 'stand strong to preserve our region, our heritage and the best aspects of our traditions, and enhance them for the benefit of future generations'. 'The bottom line', it revealingly declared, 'is that future inter-country relationships will need to be closer and more mutually supportive if the region is to avoid decline and international marginalisation' (emphasis added). What was really meant, in keeping with the predominant orientation of the regional economic and trade policy agenda, was the promotion of economic integration. The report's inclusion of a proposal for a Pacific Plan, 'to create stronger and deeper links between the countries of the region' made this purpose crystal clear.

The rhetoric in the EPG report became the main focus of criticisms of the plan. Huffer, for instance, highlighted the EPG's stress on the need for a 'focus on people' in the regional plan, noting particularly its pronouncement that 'together we shall work to ensure that this is a region where people matter more than anything else, and where every person feels loved, needed and able to enjoy a free, responsible and worthwhile life' (Huffer 2006b, p. 44). That the resulting Pacific Plan endorsed by the Pacific leaders in 2005 bore little resemblance to the EPG's poignant reflections was explained by the fact that the Pacific Plan was drafted by a Pacific Islands Forum Secretariat (PIFS) supported taskforce which based its approach on a technocratic Asian Development Bank report, titled 'New Pacific Regionalism', written by the one-time head of the forum secretariat's trade division, economist Roman Grynberg. According to Huffer, the taskforce identified three 'quite different concepts of regionalism - regional cooperation, regional provision of public goods and services, and regional integration', and advocated shifting from regional cooperation to either of the other forms of regionalism on the basis of a cost/benefit analysis - 'regional approaches to overcoming capacity limitations in service delivery at the national level, and increasing economic opportunities through market integration' were expected to bring the highest gains (Huffer 2006b, p. 44). Huffer rightly perceived the Pacific Plan as setting: 
an agenda for new levels of regional integration whereby Pacific Island countries will gradually relinquish sovereignty over certain areas of governance, economic policy and security. As such it sets the framework for a new political and economic order, even though the latter may be introduced incrementally (Huffer 2006a, p. 158).

NGO criticisms of the Pacific Plan similarly highlighted the disjunction between the rhetoric in the EPG report, and the Pacific Plan. Following a regional NGO meeting in Port Moresby in October 2005, Greenpeace Oceans campaigner Lagi Toribau said that, despite considerable rhetoric about security, the Pacific Plan failed to address 'true security for Pacific Island communities, such as health, food and real energy security' (Hamed 2005). NGOs at that meeting also berated the Pacific Plan's drafters for failing to consult Pacific people. They called for a two-year moratorium on the plan to enable 'a more comprehensive and genuine consultation process' to take place and 'informed consent' to be obtained from Pacific people (Pacific Magazine 2005). A subsequent meeting of Pacific NGOs in Nadi in October 2006, convened by Oxfam New Zealand, reiterated civil society criticisms of the Pacific Plan, and particularly of 'planned trade deals'. Slatter and Underhill-Sem dubbed the Pacific Plan 'a neoliberal framework for regional market integration', noting its coherence with PIFS' regional economic and trade liberalisation agenda, and its substitution of 'political regionalism' (organised resistance by Pacific Island states to powerful outside interests that pose threats to Pacific Islands interests) by the new regionalism of market integration (Slatter and Underhill-Sem 2009, p. 197).

There was little doubt about which of the plan's four pillars - sustainable development, economic growth, good governance, and regional security lay at its core. Indeed, stripped of the rhetoric, the Pacific Plan was revealed as little more than a road map for regional market integration. Market integration or economic integration is 'tradespeak' for free trade. Amongst other things, the Grynberg report had proposed a broadened Pacific Agreement on Closer Economic Relations (PACER), with investment, services and labour mobility added to free trade in goods, and a binding legal instrument involving trade, aid and governance commitments for forum island countries (FICs). ${ }^{2}$ These farreaching proposals for the proposed free trade agreement between Pacific Island states and Australia and New Zealand, which subsequently came to be called PACER Plus, were anticipated to meet considerable opposition from the few losers', who the Grynberg report described as 'often well-organised, vocal, and in a position to effectively oppose reforms' (Asian Development BankCommonwealth Secretariat 2005, p. 148).

2 The Grynberg report proposed a binding agreement on good governance undertakings for Pacific Island states, in return for a renewable five- to 10-year aid and trade agreement (Asian Development BankCommonwealth Secretariat 2005). 
Regional specialist Greg Fry aptly termed the exogenously conceived and neoliberal-inspired new Pacific regionalism 'hegemonic regionalism' (Fry 2004, p. 11). The hegemonic framing of regional priorities was not surprising as PIFS had been occupied for more than a decade in facilitating an externally driven, region-wide, economic restructuring and trade liberalisation agenda. The overweening role of New Zealand and Australia within the Pacific Islands Forum, which derived in large part from their almost total financing of the PIFS $^{3}$ and effective control of key positions, had helped make it a conduit for regionally implementing donor-driven reforms.

\section{Submissions to the Review Committee by Non-State Actors}

Although 37 NGOs and CSOs were reported to have made submissions to the Pacific Plan Review Team, 18 of these submissions were made by international NGOs, 17 by individuals, and four by private sector non-state actors (NSAs). Highlighted below are the submissions made by regionally-based NGOs and CSOs which critiqued the development model embraced by the Pacific Plan and offered an alternative development vision. Submissions from non-regionally based NSAs which shared this critique, and its alternative vision, are also mentioned.

The Pacific Regional Non-Governmental Organisation (PRNGO) alliance, representing 13 regional NGOs 'backed by strong networks across the Pacific', confined its submission to concerns about the inadequacy of the PIFS Framework for Engagement with NSAs. It said some NGOs had limited access to regional meetings convened by PIFS and CROP (Council of Regional Organisations in the Pacific) agencies, but this was 'based on personal relationships and remains this way because credible and sincere engagement with regional NGOs is not institutionalised'. It alleged that private sector NSAs were accorded 'preferential treatment.'

The Pacific Islands Association of Non-Government Organisations (PIANGO), a regional coordinating body of umbrella NGOs in 21 Pacific countries, titled its submission, 'The Pacific We Want: A new Pacific regional architecture' and called for both 'formal institutional recognition of CSOs as legitimate development actors', and 'a rethinking of development and reshaping of the Pacific we want'. PIANGO did not support a continuing focus on economic growth and regional integration in the Pacific Plan, saying there was now

3 According to Greg Fry (2015), based on 2013 figures, Australia and New Zealand contribute 94 per cent of the PIF core and regular budget bill, while FICs contribute a mere 5 per cent. 
'strong consensus that economic growth does not necessarily lead to improved human development and sustainability', and that the Pacific Plan must deliver 'a transformative development agenda which is human development centred' (Pacific Plan Review 2013a).

The Pacific Network on Globalisation (PANG) submitted that 'the emphasis in the Pacific Plan's economic pillar on neoliberal economics must be re-thought' and framed with consideration of Pacific peoples' right to economic selfdetermination. It referred to 'growing evidence of the negative impacts of the neo-liberal economic model promoted by the Pacific Plan on the lives and livelihoods of Pacific peoples', and suggested that alternative models of development could be 'derived from embedded traditional communal values such as stewardship, sharing, caring and reciprocity'. The challenge lay in 'having the courage to step forward on such a path and define regionalism on our own terms' (Pacific Plan Review 2013a).

A statement adopted by a meeting of Pacific Young Women Activists on Gender, Economic and Climate Justice, convened in September 2010, submitted to the review team, called for 'development alternatives, policies and programmes that empower communities, families and individuals'. Another statement, from a meeting of Pacific feminists and activists in Nadi in February 2013, reminded Pacific states of their obligations and accountability 'to translate gender equality and human rights commitments into law, policy and budget allocations, and to make these norms and standards the guiding principles for contemporary Pacific societies, to be reflected in ... the Pacific Plan Review' (Buadromo et al. 2013).

Two NSA submissions by organisations based outside of the Island Pacific shared the alternative visions of regionally based NGOs. Oxfam New Zealand said the Pacific Plan review 'needs to be framed with the Pacific's people at its core', and future plans should 'build on the Pacific's strengths' of 'social cohesion and resilience, respect for tradition, vibrant cultures, equity and fairness and livelihood opportunities for all'. These foundations, it submitted, 'should not be sacrificed in ambitious plans for economic growth for the few, or economic infrastructure'. World Vision called for 'sustainable management of natural resources including protection of biodiversity; security of land rights of communities and indigenous peoples, especially in the face of extractive industries and infrastructure projects; and ensuring lands and vital resources of communities are free from security risks'.

A personal submission by Noelene Nabulivou, Development Alternatives with Women for a New Era (DAWN), proposed binding development safeguards for all peoples of the Pacific, and highlighted the incoherence in policy between setting up marine protected areas on the one hand, and working towards deep sea mining on the other. 
Several NSA submissions called for gender equality targets, including targets and indicators for combating gender-based violence. Pacific Women's Parliamentary Partnership, in a submission signed by New Zealand MP Louisa Wall and Samoan Government Minister Fiame Mata'afa, called for indicators and measures for good governance at the judicial and local government levels. They proposed 30 per cent parliamentary representation for women in Pacific Island states and national progress reports on implementation of PIF's Declaration on Gender Equality.

Four submissions raised specific attention to the need to prioritise human rights protection in the revised Pacific Plan. Diverse Voices and Action for Equality (DIVA) called for the inclusion of two rights-based principles non-discrimination and right to security of the person - with special attention to the rights of Pacific intersex and trans* people and lesbian, bisexual and trans women.

In summary, the NGO submissions highlighted partnership with NSAs, economic self-determination, people-centred (as opposed to economic growthcentred) development, Pacific values, the need to safeguard land and other resources, gender equality, and protection of human rights for all people in Pacific Island states.

\section{The Pacific Plan Review Process}

In response to the barrage of criticism, the Pacific Plan was flagged as a 'living document'. In 2009 it underwent a review by an independent consultant, Makurita Baaro, following which the sustainable development pillar was broadened to include responding to climate change and improving livelihoods and well-being. Five themes and 37 priorities were adopted. The subsequent comprehensive review of the Pacific Plan, which resulted in its recasting as the Framework for Pacific Regionalism, began in December 2012, with the appointment of the review team led by Sir Mekere Morauta.

In contrast to the top-down process of formulating and adopting the Pacific Plan, the Pacific Plan review process was widely consultative, participatory, and transparent. Given the harsh criticism of the Pacific Plan by NGOs, academics and other stakeholders, there was a clear intention to provide NSAs with the opportunity to contribute to revising the plan. From January to May 2013, the review team held country consultations and received public submissions. In all, the team made 18 country visits (including to New Caledonia and French Polynesia), consulted 700 stakeholders, and received almost 70 online submissions (65 of which were made available online with the consent of those 
who submitted), and commissioned studies on some specific issues. A regional consultation workshop was convened in May 2013, together with a special session of the Pacific Plan Action Committee. Further consultations followed in June and July before the annual meeting of the Pacific Plan Action Committee in August considered review working papers. In October 2013, following the leaders meeting in Majuro the month before, the Final Pacific Plan Review Report, comprising 36 recommendations, was submitted.

The full report was made publicly available in December 2013, following discussion by the Forum Officials Committee. At a special leaders retreat on the Pacific Plan Review in May 2014, the Pacific Plan was recast as the Framework for Pacific Regionalism.

\section{Unpacking the Framework for Pacific Regionalism}

According to Sir Mekere Morauta, the Framework for Pacific Regionalism should be viewed 'as a framework for advancing the political principle of regionalism through a robust, inclusive process of political dialogue, the expression of political values about regionalism and sovereignty, and the decisive implementation of key, game-changing, drivers of regional integration' (cited in PIFS 2014).

Pacific Plan Adviser at the PIFS, Seini O'Connor, elaborated on the framework at a Pacific update meeting in Canberra, June 2014, confirming the clearly intended involvement of NSAs in the process of deciding regional priorities. The framework, she said, would:

support a tighter, more focused forum agenda, with space for just a few 'big issues' to be discussed by political leaders at their annual retreat. It will promote the development of large-scale initiatives that bring together development partners, regional agencies and non-state actors with plans of action, rather than just good ideas. It will complement effective sub-regionalism. And it will support recognition for leadership to be shown in other areas: for ministers to drive regional cooperation through decisive collective action, for officials to provide direction to their regional organisations when they sign off on annual work plans, and for the vast range of actors outside of government to be involved in proposing and deciding what the region should focus its efforts on ( $\mathrm{O}^{\prime}$ Connor 2014).

Essentially, the framework consists of a brief vision statement (of a 'region of peace, harmony, security, social inclusion and prosperity, so that all Pacific people can lead free, healthy and productive lives') and six values, which cover:

1. the integrity of our vast ocean and island resources;

2. the diversity and heritage of the Pacific and inclusivity; 
3. good governance, democratic values, the rule of law, human rights, gender equality and just societies;

4. peaceful, safe and stable communities and ensured full security and wellbeing for Pacific peoples;

5. full inclusivity, equity and equality for all people of the Pacific; and

6. effective open and honest relationships and inclusive and ensuring partnerships based on mutual accountability and respect with [sic] each other, within sub-regions, within the region, and beyond.

There are also four stated objectives, which elaborate concisely but more explicitly the objectives of the four original pillars of the Pacific Plan: sustainable development 'combines economic, social and cultural development in ways that improve livelihoods and well-being and use the environment sustainably'; economic growth is 'inclusive and equitable'; good governance is 'strengthened governance, legal, financial and administrative systems'; and regional security is holistically defined in terms of ensuring 'stable and safe human, environmental and political conditions for all'.

The framework includes a matrix of six different 'forms of regionalism' or of regional collective action, which can be adopted by Pacific countries to support a regional initiative that has been proposed and adopted by Pacific Island countries (states or non-state actors) following a carefully elaborated process for priority setting. Prioritisation of a regional initiative and progress reports on its implementation will be evaluated against six criteria or tests for regional action, namely:

1. a market test (the initiative should not involve a service which markets can provide well);

2. a sovereignty test (it should involve no loss of national sovereignty);

3. a regionalism test (it should satisfy one of seven criteria - for example, establish a shared norm or standard, establish a common position on an issue, deliver a public good which is regional in scope, realise economies of scale);

4. political oversight (it should require the leader's attention and input);

5. a risk and sustainability test (be based on a thorough risk and sustainability evaluation, a sound implementation plan, with funding and human resources capacity); and

6. a duplication test (it should not be already in progress by another organisation or duplicate another initiative).

The framework proposes no specific regional projects, but sets up a process through which proposals for regional initiatives are received annually from Pacific states and NSAs and assessed by an independent sub-committee, with five 
proposals selected for implementation each year. This essentially puts the onus on states and NSAs (private sector organisations or individuals, citizen groups, academics, development practitioners, etc.) to propose regional initiatives each year for selection by the committee. All proposals will be posted online for public information, although reasons behind the selection of the five initiatives will not be publicly disclosed. ${ }^{4}$

\section{Pacific Plan Review: Report to Pacific Leaders}

Making an assessment of the framework requires examining the Pacific Plan Review Report, which explicitly advocated a particular model of regionalism. It said, 'regionalism is in the first instance a political, not technical, process', and that the overwhelming message from citizens across the region was that 'the right conversations are not being had about the region's new vulnerabilities', and 'citizens' voices are not being heard about what kind of Pacific is emerging in the absence of coherent, effective regional governance' (Pacific Plan Review 2013 b, p. 54). The Pacific Plan 'lacked ownership' and there was 'a lack of space in the Forum for the kind of political conversations' needed (Pacific Plan Review 2013 b, p. 55). A 'largely officials-led process, in which clarity over who are the principals in, and who are the agents of, regionalism has become confused' had resulted in CROP agencies 'prosecut[ing] their own [largely technical] agendas'. One observer was quoted as having said 'we have created a superstructure of institutions and processes to prioritise, mandate and report on something that is ultimately not widely valued, and which does not effectively drive regionalism'. The review committee had concluded that 'an overhaul of the processes, institutions and governance of the Plan', was needed to progress regionalism.

The kind of conversation the review committee thought was needed, however, was clearly rather different from the conversations amongst non-private sector NSAs. The review report made a number of recommendations, including that 'PIFS works with multilateral finance institutions' to 'offer PICs the opportunity to develop more highly prioritized growth strategies', and that PIFS 'investigates the merits of establishing a self-funding Secretariat to assist PICs with the development of seabed mining'. ${ }^{5}$ The report showed no evidence of having taken on board any of the concerns raised in the submissions from Pacific NGOs.

\footnotetext{
4 Interview with Pacific Regionalism Adviser at Pacific Islands Forum Secretariat, Joel Nilon, 8 May 2015. It also recommended PIFS work with multilateral finance institutions to 'examine issues relating to reasonable standard of living' and to 'develop uniquely Pacific indicators of both poverty and progress'.
} 
In a section subtitled 'Paths to Deeper Integration', the report diagrammatically set out 'the sort of path' the review committee had in mind, showing progressive advance from regional cooperation (for example, strong external voice such as statement on climate change), to shared service delivery (for example, the University of the South Pacific or Secretariat of the Pacific Community technical assistance), to economic integration (for example, free trade agreement and labour mobility), to political integration (for example, shared supreme court), to political union (for example, European Union, Organisation of Eastern Caribbean States), to, ultimately, federation (for example, establishing a single political entity, such as united Germany) - 'usually irreversible' (Pacific Plan Review 2013b, p. 88). The given examples of regional integration towards federation reflect an unequivocal emphasis on economic integration features that are consistent with neoliberalism, namely free trade agreement, harmonised business regulation and business law, labour mobility, investment liberalisation, customs union, and common currency. Examples of political and administrative integration towards federation include shared supreme court, central government body to manage the region, shared defence force, transfers between countries, and supra-national law-making and taxation powers (Pacific Plan Review 2013, p. 90). It was acknowledged that it is 'the prerogative of the people of the Pacific and their leaders' to decide how far along this path the Pacific should go - and that leaders had only expressed an interest in discussing further integration, and had made no decision to follow this path (Pacific Plan Review 2013, p. 89).

The emphasis on economic and deeper integration was very pronounced in the first draft of the new framework. It is substantially muted in the final framework, evidently in response to feedback on the first draft, not least from NSAs, and this was very likely motivated in part by a need to avoid being subjected, yet again, to major criticism.

\section{Implementing the Framework}

The process of implementing the framework began with the establishment of the independent sub-committee to receive proposals, assess them against the six tests, and select the five for implementation. PIFS called for applications for the sub-committee in December, closing in February. A sub-committee of seven standing members was subsequently appointed by a troika comprising the present, incoming and last chairs of the PIF, and although it was not intended to be a representative body, its membership includes one from each of the three sub-regions of Melanesia, Micronesia and Polynesia, one from a small island state, and one each from the private sector, civil society, and Australia and 
New Zealand. ${ }^{6}$ Chaired by the Secretary General of PIFS, Dame Meg Taylor, the sub-committee has already met and considered gaps in their expertise and the weighting to be given to each of the six tests. An announcement and explanation of the process, together with a template for proposal submissions, was published in April, under the heading 'Listening to the Pacific', with 12 June 2015 set as the submissions deadline. Apart from providing the chair, the role of PIFS will be confined to receiving proposals and checking for completeness.

\section{How New is the Framework for Pacific Regionalism?}

The framework is very focused on processes - for priority setting, testing for regionalism, assessing progress reports, and ensuring that politically sensitive and major regional issues are the focus of leaders meeting agendas. Its open process and inclusivity has been conceived in recognition of some of the failures of the Pacific Plan. ${ }^{7}$ This distinctive new feature - openness to and inclusion of proposals from NSAs for priority attention by governments - seems to signify a radical shift from the previous state-centric model of regional agenda setting, and a changed role for PIFS, which has long been facilitating a donordriven regional agenda of economic reform and trade liberalisation. The new framework's narrowing of priority issues to be given leaders' attention each year to just five, and its vesting of decision-making to an independent subcommittee, are also distinctively novel features.

While it remains to be seen what proposals are endorsed as regional priorities, the framework does respond to concerns raised in NGO submissions in two ways: firstly, by incorporating into the framework values which resonate with those highlighted by NGO submissions; and secondly, by instituting an open and inclusive process in which NGO and government proposals are equally assessed and selected for implementation by an independent body.

It may be coincidental, but the new framework appears to concur with the submission by the International Institute for Democracy and Electoral Assistance (IDEA), an international NGO that made a submission to the review team. IDEA commended the Pacific Plan review ream for seeking first the input of citizens and communities on the development process and political reform agenda, saying: 'when the necessity for regional integration emerges from such input ... it will then draw life and legitimacy in a way that is impossible from

\footnotetext{
6 According to an NGO source, neither the NGO nor the private sector 'representative' on the subcommittee are known individuals, and are not known to be connected to established NGO or private sector networks.

7 Interview with Joel Nilon, 8 May 2015.
} 
the more technical model that focuses primarily on leaders, executive arms of government and funding agencies ... The revised Pacific Plan needs not only to address the substantive issues of development, but the process by which development priorities are identified and validated - and the process by which their legitimacy and relevance [are] retained and their implementation undertaken, its effectiveness overseen, and its shortcoming identified and addressed' (Pacific Plan Review 2013a).

Through the open, inclusive and independent process of the new framework, PIFS is stepping back from a position of pushing policies, seeking instead broad ownership of the framework by Pacific Island people. Dame Meg Taylor's 'listening tour' of Pacific Island states - since taking up the job of secretary general she has been travelling to each of the FICs to ascertain for herself current thinking on regional priorities - is indicative of the importance of the framework to PIFS. Recent challenges to, and destabilisation of the established intergovernmental regional architecture (see Tarte 2014) have almost certainly impacted on the implementation of the Framework for Pacific Regionalism. Indeed, getting buy-in for the framework and making its inclusivity work may recover legitimacy for PIFS. On the positive side, the framework does open a window of opportunity for NGOs to submit proposals and make a case for priority to be given to some of their specific concerns by aligning proposed initiatives to the framework's vision, values and objectives.

Yet, by remaining silent on calls by NSAs for a fundamental shift in the development model being followed by Pacific Island states, the framework may function to simply divert attention from the main agenda of economic integration. While the values and objectives of the framework resonate with sentiments expressed in a number of NGO submissions, the over-emphasis on economic integration in the review committee's report suggests that this is deeply embedded and will remain PIFS' core aim and objective. PIFS maintains that, although economic and trade proposals may be submitted and selected, there is no bias in the framework towards economic integration. ${ }^{8}$

To conclude, on the face of it, the Framework for Pacific Regionalism appears to be serving up a more palatable kava mix than was offered in the Pacific Plan tanoa. But it is still too early as yet to be able to say whether the new processes of inclusivity will substantially change the focus of regional policy making and the development path along which Pacific Island states are being driven. The selection of initiatives may well include those proposed by concerned civil society actors and thereby address issues they raised in their submissions to the review team, however, it is not clear what the current vision of Pacific leaders 
is. More concerning, there seems to be a very evident disjunction between the elements of the finalised framework and the model outlined in the review team's report. This raises questions about the meaning of selecting five initiatives for the leaders to give attention to each year, if the primary focus of PIFS remains unchanged. For NGOs, the jury is still out on the framework.

\section{References}

Asian Development Bank-Commonwealth Secretariat, 2005, 'Toward a New Pacific Regionalism', Asian Development Bank-Commonwealth Secretariat Joint Report to the Pacific Islands Forum Secretariat. Available at: www.adb. org/sites/default/files/publication/28797/pacific-regionalism-vol2.pdf.

Buadromo, V. et al., 2013, 'Pacific Feminists and Activists: Re-framing, Re-articulating and Re-energizing Sexual and Reproductive Health and Rights'. Available at: www.pacificwomen.org/wp-content/uploads/PacificSRHR-2013-Outcome-Doc.pdf.

Coates, B., 2006, 'Reorienting Economic Growth in the Pacific Plan: Towards equitable and sustainable development', presentation to Pacific Civil Society Forum, Nadi, Fiji. Available at: www.oxfam.org.nz/sites/default/files/reports/ Analysis_PPlan_Oct06.pdf.

Eminent Persons Group (EPG), 2004, 'Pacific Cooperation: Views of the region', The Eminent Persons Group Review of the Pacific Islands Forum. Available at: gsd.spc.int/sopac/docs/RIF/05_EPG_Report_April04.pdf.

Fry, G., 2004, 'Whose Oceania?: Contending visions of community in Pacific region-building', Working Paper 2004/3, Department of International Relations, RSPAS, The Australian National University, Canberra.

Fry, G., 2015, 'Recapturing the Spirit of 1971: Towards a new regional political settlement in the Pacific', SSGM Discussion Paper 2015/3, The Australian National University, Canberra.

Hamed, O., 2005, 'Neo-Colonialism Ratified At Pacific Islands Forum', Just Focus: Youth focus for a just world. Available at: www,justfocus.org.nz/ articles/2005/11/04/neo-colonialism-ratified-at-pacific-islands-forum/.

Huffer, E., 2006a, 'The Pacific Plan: A political and cultural critique', in J. Bryant-Tokalau and I. Frazer (eds), Redefining the Pacific?: Regionalism past, present and future, Ashgate Publishing Limited, Aldershot. 
Huffer, E., 2006b, 'Regionalism and Cultural Identity: Putting the Pacific back into the plan', in S. Firth (ed.), Globalisation and Governance in the Pacific Islands, ANU E Press, Canberra, pp. 43-55.

O'Connor, S., 2014, 'Session: Regionalism — responding to the Pacific Plan Review'. Available at: devpolicy.org/presentations/2014-Pacific-Update/Day2/Seini-O-Connor.pdf.

Pacific Islands Forum Secretariat (PIFS), 2014, 'The Framework for Pacific Regionalism' Available at: www.adb.org/sites/default/files/linkeddocuments/pacific-robp-2015-2017-sd.pdf.

Pacific Magazine, 2005, 'Moratorium Call for Pacific Plan', September 15. Available at: www.pacificislands.cc/pina/pinadefault2.php?urlpinaid $=16889$.

Pacific Plan Review, 2013a, 'Public Submissions'. Available at: www. pacificplanreview.org/submissions/.

Pacific Plan Review, 2013b, 'Report to Pacific Leaders', Pacific Islands Forum Secretariat, Suva, Fiji. Available at: www.cid.org.nz/assets/Key-issues/ Pacific-development/Pacific-Plan-Review-2013-Volume-1.pdf.

Slatter C. and Y. Underhill-Sem, 2009, 'Re-Claiming Pacific Island Regionalism: Does neo-liberalism have to reign?', in K. L. Koo and B. D'Costa (eds), Gender and Global Politics in the Asia-Pacific, Palgrave Macmillan, New York, pp. 195-210.

Tarte, S., 2014, 'Regionalism and Changing Regional Order in the Pacific Islands', Asia and the Pacific Policy Studies 1(2), pp. 312-24. 
This text is taken from The New Pacific Diplomacy, edited by Greg Fry and Sandra Tarte, published 2015 by ANU Press, The Australian National University, Canberra, Australia. 